\title{
Umrah Bailout Funds on the Finance Companies Platform According to Islamic Law: a Lesson From Indonesia
}

\author{
Abdul Haris ${ }^{1}$, Waridah ${ }^{2}$ \\ harisabdul716@gmail.com \\ Fakultas Isipol Universitas Medan Area ${ }^{1,2}$
}

\begin{abstract}
Public mistrust of the companies that run Hajj and Umrah pilgrimages as a result of an Umrah travel company that cheats prospective pilgrims, has encouraged Umrah travel companies to innovate by cooperating with companies that have financing products for the departure of the Umrah pilgrimage. The Objective of this study is to analyze decisions pilgrims who use the bailout facilities to worship Umrah, analyze the use of Umrah pilgrimage funds according to Islamic law and analyze Islamic financial institutions that provide bailouts. By using a qualitative descriptive method data collection techniques used were documentation and in-depth interviews studies are expected to open broad thinking horizons in deciding the use of bailouts for worship. The results showed that Shohibah Shidiqoh Abadi as a company organizing pilgrimage and pilgrimage pilgrimage has a program of departure Umrah promo with the system, go first, pay in the holy land, and depart first pay after returning without DP / down payment. In its operational activities Shohibah Shodiqoh Abadi cooperates with PT. Arofah and Amitra Syariah as a financing company and the payment system provided is a murobahah (buying and selling) system. According to Islamic law the financing system run by Amitra Syariah and Shohibah Shodiqoh Abadi is no prohibition. As an innovation in the financial sector of Islamic low system offered can be a solution for prospective pilgrims who want to carry out the Umrah. Payment of bailouts in installments according to ability, without late fees and without usury has become an attraction for pilgrims deemed capable. The result of this study concluded that use of bailouts for worshiping Umrah is permissible. Society can use the facilities offered by the company shohibah shodiqoh eternal by still paying attention to the terms of sale and purchase in accordance with the laws of buying and selling in Islam.
\end{abstract}

Keywords: Bailouts, Umrah, and Islamic law.

\section{Pendahuluan}

Indonesia adalah negara berpenduduk mayoritas muslim dengan populasi terbesar di dunia. Oleh karena itu, Indonesia berpotensi untuk mengembangkan perekonomian dibidang ekonomi syariah. Pemerintah Indonesia telah memberikan kemudahan dalam mendorong perekonomian berbasis syariah. Agar dapat tumbuh dan berkembang, maka melalui beberapa aturan dan regulasi yang tegas pemerintah berkomitmen melalui Undang-Undang Perbankan Syariah dan Undang-Undang Sukuk. Komite Nasional Keuangan Syariah atau KNKS yang dibentuk oleh pemerintah memberikan prioritas kepada Lembaga Keuangan Syariah (LKS). Rencana Pembangunan Jangka Menengah Nasional (RPJMN) Tahun 2015-2019. Telah memasukkan LKS di dalamnya. Masyarakat Indonesia memang memiliki daya ketertarikan terhadap sesuatu yang berbau Syariah sehingga awareness yang tinggi ini membuat LKS sangat 
bersemangat untuk berjuang mendapatkan nasabah sebanyak mungkin. Ini semua tentu dilatarbelakangi oleh sikap religius masyarakat. Hal ini sejalan dengan semangat pemerintah.

Bisnis dan pembiayaan yang bersandarkan pada Syariah dirasa sudah menjadi gaya hidup yang telah berkembang menjadi kebutuhan masyarakat saat ini. Ketertarikan dan keinginan masyarakat terhadap peluang bisnis yang berbau Syariah telah melanda semua lapisan masyarakat bisnis. Golongan yang menamakan dirinya kelompok mileneal atau dikenal dengan generasi $\mathrm{Z}$ sudah menggandrungi bisnis secara Syariah. Ini terbukti dari pengusaha-pengusaha muda yang mengkaitkan usaha mereka dengan gaya hidup yang Islami.

Pembiayaan syariah, perbankan syariah, dan lain sebagainya yang berlandaskan hukum Syariah telah melanda khalayak ramai di negeri Indonesia. Hal ini sangat menarik karena sebagian besar masyarakat Indonesia beragama Islam. Namun yang lebih menarik adalah situasi ini telah menarik juga buat mereka yang yang bukan beragama Islam. Mereka ingin berbisnis secara Syariah Islam. Maka sudah terbayang betapa besarnya potensi bisnis yang akan dihasilkan. Begitu menarik dan mudahnya program-program pembiayaan yang berbasis syariah telah menciptakan peluang bagi masyarakat untuk ambil bagian pada program ini. Dan oleh karena masyarakat Islam merupakan objek program pembiayaan ini maka perlu dilakukan pengkajian tentang program yang ditawarkan ditinjau dari sudut pandang Syariah Islam.

Sistem keuangan dipahami sebagai satu kesatuan peraturan yang mengatur dan mengendalikan aliran dana dari unit pengeluaran surplus (SSU) ke unit defisit pengeluaran (SDU) [1]. Sistem keuangan Islam, menurut definisi, menyediakan hubungan antara SSU dan SDU melalui serangkaian produk dan layanan keuangan yang tidak melanggar norma-norma etika Islam. Cendekiawan Islam tidak hanya menetapkan prinsip-prinsip dan norma-norma dasar, tetapi juga mengidentifikasi mekanisme kontrak yang sesuai dengan norma-norma ini dan tidak melanggarnya dengan cara apa pun [2] Sebagai bagian dari sistem keuangan, prinsip dasar perbankan Islam adalah pembagian keuntungan dan kerugian serta diharamkannya bunga (riba). Konsep Islam yang sering dipergunakan dalam perbankan Islam adalah mudharabah (bagi hasil), wadiah (penyimpanan), musharakah (usaha patungan), murabahah (biaya dan penjualan), dan Ijaroh (sewa guna).

Dua bentuk mode pembagian keuntungan dan kerugian, yang sering disebut dalam literatur fiqh adalah mudharabah dan musharakah. Dalam musharakah, laba bank atas pinjaman dihitung berdasarkan persentase tertentu dari laba nasabah. Sesudah jumlah pokok pinjaman lunas, baru diatus pembagian keuntungan diputuskan. Selanjutnya, mudharabah adalah pendanaan modal ventura seorang pengusaha yang mengambil suatu pekerjaan dengan menyediakan tenaga kerja, untuk pembiayaan atas pekerjaan itu diajukan kepada bank selaku penyandang dana sehingga keuntungan dan risiko dibagi antara pengusaha tadi dengan bank. Pengaturan partisipatif antara modal dan tenaga kerja menperlihatkan konsep yang berlaku dalam Islam bahwa peminjam tidak dibolehkan menanggung semua risiko/biaya ketidak berhasilan (kegagalan), hal ini akan menghasilkan penyebaran pendapatan yang adil dan seimbang dan tidak memberikan kesempatan pada pemberi pinjaman menguasai dan memonopoli perekonomian.

Musharakah adalah hubungan yang didirikan berdasarkan kontrak dengan persetujuan bersama dari para pihak untuk berbagi keuntungan dan kerugian dalam bisnis bersama. Ini adalah perjanjian di mana penyandang dana (bank syariah), menyatukan dengan dana perusahaan, dan dana-dana lain. Para penyanadang modal memiliki hak untuk berpartisipasi dalam kegiatan manajemen, walaupun bukan keharusan untuk melakukannya. Keuntungan dibagikan di antara mitra dengan jumlah pembagian yang telah disepakati sebelumnya, sementara itu kerugian ditanggung oleh masing-masing mitra diatur secara ketat sesuai dengan kontribusi modal masing-masing. 
Konsep inilah yang membedakan secara jelas dan tegas dengan investasi pendapatan tetap.

\section{Pembahasan}

\subsection{Analisa PT. Shohibah Shodiqoh Abadi}

Legalitas Perusahaan PT. Shohibah Shodiqoh Abadi ditandai dengan:

a. Tanda Daftar Usaha Kepariwisataan nomor 17/03.03/DPMPTSP/I/2018 di Pekanbaru.

b. Surat Keterangan Fiskal No. 3383/03.02/DMPPTSP///2018

c. Keputusan Menkumham No. AHU-0002891.AH.01.01, Tahun 2018

d. Tanda Daftar Pemeriksaan Alat Proteksi Pemadam Kebakaran No. 35/TDPPK/DPMPTSP/I/2018

e. Akte Pendirian No. 13, Notaris IGAR RIKARNA, SH, di kota Pekanbaru

Berdasarkan izin-izin di atas maka PT. Shohibah Shodiqoh Abadi, menjalan usaha perjalanan wisata, dengan slogan simple, quick \& excellent perusahaan ini menawarkan jasa perjalanan umroh. Dalam operasionalnya Shohibah Shodiqoh Abadi (SSA) bekerja sama dengan NBRAS AL Maha Co. yang beralamat di Mandiri Tower II.12 Floor\#78-84 Jl. Jend. Sudirman Jakarta Selatan 12190 Indonesia dan perusahaan pembiayaan syariah, AMITRA Syariah Financing dengan web http://www.fifgroup.co.id (info lengkap). Wilayah operasinal di Pekanbaru dan menunjuk beberapa perwakilan di daerah lain seperti Medan, Padang, dan Makassar. Platform perusahaan pembiayaan perusahaan pembiayaan yang bekerja sama dengan SSA adalah AMITRA Syariah.

Amitra adalah anak perusahaan pembiayaan FIF, yang menjalankan operasionalnya mendapat pengawasan dari Dewan Syariah Nasional Majelis Ulama Indonesia. Amitra hadir untuk membantu menyelesaikan persoalan masyarakat dalam hal pembiayaan Syariah. Hal ini sesuai dengan harapan masyarakat saat ini. Sistem yang ditawarkan AMITRA adalah kemudahan proses dan transparan, serta biaya yang kompetitif.

\subsection{Platform Perusahaan Pembiayaan}

Shohibah Shodiqoh Abadi bekerjasama dengan AMITRA Syariah. Amitra merupakan grup dari perusahaan pembiayaan FIF sebagai anak perusahaan, dan selalu di awasi oleh Dewan Syariah Nasional dalam operasionalnya. Sebagai perusahaan yang bermotto memberikan solusi kepada masyarakat yang membutuhkan pembiayaan sesuai Syariah, hal ini sangat membantu dan sangat sesuai dengan apa yang menjadi harapan masyarakat. Kemudahan proses dan transparansi yang ditawarkan menjadikan AMITRA sebagai alternatif pilihan di masyarakat karena berbiaya kompetitif.

Sistem Murobahah yang ditawarkan berdasarkan:

1. Pembiayaan Murobahah sesuai Fatwa DSN-MUI No. 4/2000:

a. Nasabah dibiayai oleh Bank untuk pembelian barang atau jasa dengan biaya setengah atau keseluruhan sesuai dengan penilaian dan kesepakatan antara Bank dengan nasabahnya berdasarkan spesifikasi dan kualifikasi. 
b. Nasabah membeli barang atau jasa kepada Bank dengan harga yanga sudah dihitung penambahan dari harga beli, keuntungan Bank adalah selisih harga beli dengan harga jual kepada nasabah.

2. Diskon dalam Murobahah sesuai Fatwa DSN-MUI No. 16/2000: adalah ketika proses jual beli Murobahah Bank Ketika belinya mendapat diskon maka harga yang dijual adalah harga beli yg sudah diskon dari suppliernya, karena diskon tersebut sesungguhnya milik nasabah.

3. Potongan Pelunasan dalam Murobahah sesuai Fatwa DSN-MUI No. 23/2002: Untuk nasabah yang bermaksud melakukan pelunas lebih cepat dari waktu yang disepakati maka maka Lembaga Keuangan Syariah boleh memberikan potongan pembayaran dari yang seharusnya namun hal ini tidak dijanjikan sebelumnya dan tidaka dicantumkan Ketika akad dilakukan.

\subsection{Skema Pembiayaan}

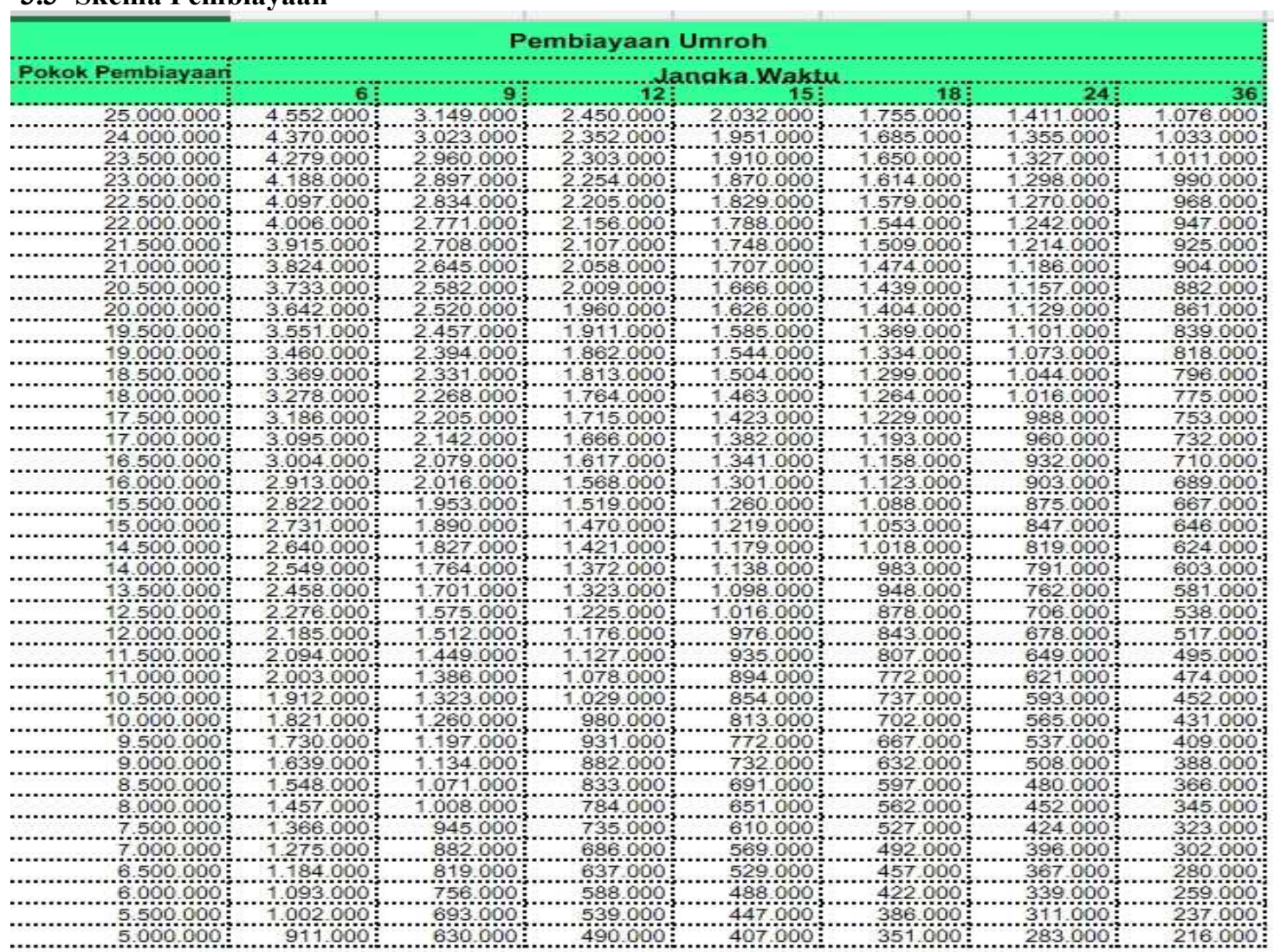

Persyaratan

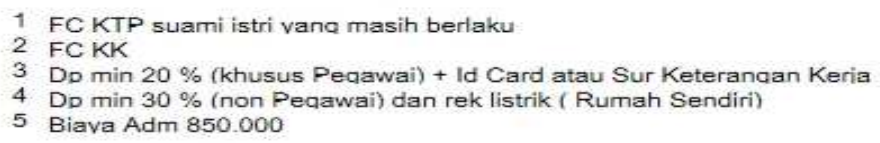

Gambar 1 Skema Pembayaran Umrah

Gambar 1 memperlihatkan jumlah pinjaman yang dibiayai mulai dari 5.000 .000 sampai 25.000.000. Dan jangka waktu pengembalian pinjaman mulai enam bulan sampai tiga puluh 
enam bulan. Jamaah yang mendapat persetujuan akan melakukan akad murobahah berdasarkan table di atas.

\subsection{Pandangan Hukum Islam}

\section{Hukum Jual Beli}

Hukum jual beli dalam Islam menurut etimologi berasal dari kata al-bay'u (jual beli) yang berarti mengambil dan memberikan sesuatu, turnannya (derivat) adalah al-baa' (depa) yang oleh kebiasaan orang Arab mengulurkan depa ketika melakukan akad jual beli dan saling menepukkan tangan sebagai symbol akad sudah dilakukan atau kejadian serupa juga dilakukan waktu mereka bertukar barang dengan uang.

Menurut terminologi, jual beli itu merupakan proses pertukaran yang berdampak berpindahnya hak kepemilikan, dan hal tersebut dapat dilakukan dengan dengan akad, baik ucapan ataupun perbuatan. (Taudhihul Ahkam, 4/211). Menurut Fiqhus sunnah (3/46) yang disebut al-bay' $u$ adalah proses pertukaran harta benda, yang dilakukan secara sukarela. Selain itu diartikan juga sebagai proses perpindahkan hak kepemilikan dari satu aoarng kepada orang lain dengan penggantian yang sudah disepakati, dilakukan dalam batasan hukum syariat hukum yang telah disepakati.

Oleh karena itu dengan disyariatkannya jual beli akan dapat mewujudkan apa yang menjadi keinginan seseorang atau sekelompok orang, alkan tetapi keinginan tersebut terkadang belum mampu diperolehnya, maka dengan adanya jual beli secara syariat itu mereka jadi mampu untuk memperoleh sesuatu yang diinginkan tersebut. Oleh karena kebutuhan seseorang tidak dapat dipisahkan dengan apa yang dimiliki orang lain (Subulus Salam, 4/47).

\section{Dalil Hukum Jual Beli}

Dasar syariat Islam mengenai jual beli terdapat dalam Al Qur'an, sunnah, ijma dan qiyas (analogi). Alqur'an surat Al Baqarah: 275, dikatakan: Alloh berfirman, Orang-orang yang memakan riba tidak dapat berdiri melainkan seperti berdirinya orang yang kemasukan setan karena gila. Yang demikian itu karena mereka berkata bahwa jual beli sama dengan riba. Padahal Alloh telah menghalalkan jual beri dan mengharamkan riba.Barang siapa mendapat peringatan dari Tuhannya, lalu dia berhenti, maka apa yang telah diperolehnya dahulu menjadi miliknya, dan urusannya (terserah) kepada Alloh. Barangsiapa mengulangi, maka mereka itu penghuni neraka, merewka kekal di dalamnya.

Al 'Allamah As Sa'diy mengatakan bahwa ada manfaat dan urgensi social di dalam jual beli, dan jika diharamkannya jual beli itu maka pasti akan menimbulkan kerugian. Oleh karena itu, hukuim asal jual beli adalah halal, terkecuali ada dalil yang mengharamkan atau larangan transaksi tersebut. (Taisir Karimir Rahman 1/116).

Menurut sunnah Nabi shallallahu 'alaihi wa sallam, profesi yang paling baik adalah yang dikerjakan oleh manusia, yaitu segala pekerjaan yang dilakukan dengan kedua tangannya dan transaksi jual beli yang dibuatnya dengan tidak melanggar aturan-aturan dan batasan-batasan yang ditetapkan oleh hukum syariat. (Hadis sahih dengan banyaknya riwayat, diriwayatkan Al Bazzzar 2/83, Hakim 2/10; dinukil dari Taudhihul Ahkam 4/218-219). "Emas 
ditukar dengan emas, perak dengan perak, gandum dengan gandum, kurma dengan kurma, garam dengan garam, sama beratnya dan langsung diserahterimakan. Apabila berlainan jenis, maka juallah sesuka kalian namun harus langsung diserahterimakan/secara kontan" (HR. Muslim: 2970), berdasarkan hadis-hadis inilah maka jual beli itu merupakan aktivitas yang dibolehkan dan tidak diharamkan secara syariat.

\subsection{Perbedaan Jual Beli dengan Riba}

Jika ada sebagian orang yang menganggap bahwa jual beli sama dengan riba, tentu anggapan tersebut hanya berlandaskan pada kenyataan bahwa para pedagang kebanyakan mengambil keuntungan sangat besar dari pembelinya. Oleh karena itu mereka tidak membedakan antara jual beli dengan riba. Argumentasi ini tentu tidak bisa dibenarkan, Allah ta'ala telah menampik anggapan seperti ini. Mari kita perhatikan firman Allah ta'ala seperti dikuti dalam surat Al-Baqoroh 275 di atas. "Orang-orang yang makan (mengambil) riba tidak dapat berdiri melainkan seperti berdirinya orang yang kemasukan syaitan lantaran (tekanan) penyakit gila. Keadaan mereka itulah yang menyebabkan mereka berkata (berpendapat), sesungguhnya jual beli itu sama dengan riba, padahal Allah telah menghalalkan jual beli dan mengharamkan riba".

Kesimpulannya adalah dana talangan untuk ibadah Umroh sesuai hukum asalnya tidak dilarang. Inovasi dibidang keuangan berbasis syariah dapat menjadi solusi ummat yang ingin melaksanakan ibadah. Penekanan bahwa tidak ada unsur riba dan denda keterlambatan dapat dijadikan daya tarik sebagai alasan yang sangat kuat untuk masyarakat melakukannya. Hukum jual beli yang diterapkan dalam sistem dana talangan Umroh menuntut kedua belah pihak patuh pada ketentuan hukum Islam. Inovasi dibidang keuangan berbasis syariah dapat menjadi solusi atau solving problem ummat yang ingin melaksanakan ibadah umroh.

\section{Kesimpulan}

Dana talangan umroh yang memberlakukan hukum jual beli, tidak ada larangan dan dapat dianggap sebagai inovasi atau ikhtiar umat yang ingin menunaikan ibadah umroh. Mengenai keuntungan yang diambil atau diberikan kepada perusahaan pembiayaan harus berdasarkan persetujuan kedua belah pihak, dan harus memperhatikan bahwa keuntungan yang diambil atau diberikan tersebut sangat dianjurkan untuk berlebihan dari harga rata-rata di pasar perbankan umunya. Walau sering terjadi bahwa perusahaan pembiayaan menggunakan mekanisme pasar dalam mengambil keuntungan yang artinya berpedoman pada hukum permintaan dan penawaran namun harus tetap bersikap santun dan toleran sebagaimana tercantum dalam Fikih Ekonomi Keuangan Islam, hal, 87, yang telah disesuaiakan. Pada suatu riwayat bahwa Nabi shallallahu 'alaihi wa sallam menyetujui waktu sahabatnya Urwah mengambil untung dua kali lipat dari harga pasar ketika diperintahkan kepadanya oleh Nabi untuk membeli seekor kambing untuk Rasululloh shallallahu 'alaihi wa sallam. (HR. Bukhari, bab 28, nomor 3642) Akan tetapi perlu menjadi perhatian bahwa memberikan kemudahan, bersikap santun, rasa puas dengan keuntungan walaupun tidak banyak, dan berharap keberkahan atas segala usaha yang dilakukan adalah sikap sesuai petunjuk para ulama salaf dan ruh syariat. Perhatikan sahabat Rasul, Ali radhiyallahu 'anhu berkata, "Hai para pedagang, ambillah hak kalian, kalian akan selamat. Jangan kalian tolak kentungan yang sedikit karena kalian bisa terhalangi mendapatkan 
keuntungan yang besar." Kalaulah seseorang ada yang merasa tertipu karena penjual memperoleh keuntungan karena menaikkan harga sehingga menjadi harganya lebih tinggi dari harga pasar sampai di luar batas kewajaran, maka dalam hukum syariat Islam diperbolehkan pembeli menuntut haknya dengan meminta kembali uang mereka yang telah dibayarkan dan membatalkan jual beli dengan mengembalikan barang yang telah dibeli tersebut kepada penjual. Inilah yang dinamakan dengan khiyarul gabn bisa dilihat pada pembahasan berbagai jenis khiyar.

Jika perusahaan pembiayaan mengambil keuntungan atas pembiayaan jamaah umroh sepanjang masih dalam koridor keuntungan yang wajar masyarakat tidak perlu ragu karena jumlah pengembalian yang sudah melalui perhitungan dan analisa syariah yang cukup mendalam.

\section{References}

[1] S. A. Rosly, "Critical Issues on Islamic Banking and Financial Markets," Dinamas Kuala Lumpur, 2005.

[2] M. Obaidullah, Islamic Financial Services. Islamic Economics Research Center, King Abdul Azis University, Jeddah, 2005.

[3] I. Febianto, "Adapting Risk Management for Profit and Loss Sharing Financing of Islamic Banks," Mod. Econ., vol. 3, no. 1, hlm. 8, 2012, doi: 10.4236/me.2012.31011.

[4] M. T. Usmani, An Introduction to Islamic Finance. New Delhi: Idara Isha'at-E-Diniyat (P) Ltd, 2005.

[5] D. Endy M. Astiwara dan D. P. S. AMITRA, Dewan Syariah Nasional. FIIS-MUI.

[6] A. Yakub dan D. P. S. A.M.I.T.R.A., Dewan Syariah Nasional. FIIS-MUI. 